\title{
Negotiations of Services Trade and Free Trade Agreement
}

\author{
Yixin Zhou \\ Harbin University of Commerce, Harbin city, Heilongjiang Province, China \\ 406809481@qq.com
}

Keywords: Negotiation of services trade; WTO; Free trade agreement; International trade

\begin{abstract}
In the global service market, service industry has surpassed global GDP by two-thirds. The status of service trade in international trade is increasingly important. Due to the complexity and time-consuming of WTO multilateral negotiations, all countries have moved from bilateral to multilateral and bilateral. This paper begins with the progress of service trade in the multilateral negotiation system, and then discusses the issue of FTA (Free Trade Agreement) regionalism and how to deal with services trade.
\end{abstract}

\section{Introduction}

The world focus on the development of service industry .It has more than two-thirds of global GDP. Therefore, what giving priority to the development of service industry and enlarging the proportion of foreign trade in trade services are common consideration in the world [1]. However, due to the particularity of services trade and services, and the fact that the WTO multilateral trade negotiations involve too many members, the negotiation process is very difficult. Therefore, regional and bilateral regional trade organizations (including FTA, and customs unions) have been set up which based on regional and bilateral preferential treatment and differential treatment.

On September 30, 2013, the Chinese government formally announced that China would participation in the negotiations on services trade. China would adhere to the principles of openness and equality during negotiations, work with all negotiating partners to push forward negotiations, and promote multilateralization of multilateral trade negotiations to bring more vitality into multilateral trade negotiations [2]. China had become the third largest country in world services trade. China fully recognized the importance of services trade and services to economic growth and social development. We would continue to promote the sustainable development of the domestic economy through the development of the domestic service industry and the expansion of the service industry to open to the outside world, to build a fair and competitive market environment.

WTO and Negotiations of Services Trade. According to the Doha Round negotiations, it planned to complete the negotiations in 2006. But what the result of the serious differences between Member States was ended. In terms of services trade, the process of negotiation was extremely difficult and some member countries had the high level of doubts about market openness[3] .

In 2001, according to the Fourth Doha Ministerial Conference Declaration, in November the same year, WTO services trade negotiations, and the resolution of the members should be done at June 30, 2002 which could make a specific commitment to the initial request before March 31, 2003 initial response[4] . However, the early stage of the process was very slowly. In 2004, the WTO passed the July Package to clarify the list of revised responses submitted by members by May 31, 2005. December 2005 The Sixth WTO Hong Kong Ministerial Conference urged all members to facilitate negotiations[5]. The specific negotiation time should be as follows: 1. Member States that had not yet submitted the initial response list should submit it as soon as possible; 2 . The request for reconsideration from the member groups to other members should be submitted as soon as possible on or after 28 March 2006; 3.Member States should finalize the rules for the special preferential treatment for developing country Members by 31 July 2006; 4. Members should submit to the Council, in accordance with the relevant provisions of the Charter of the United Nations, and submit the draft final commitment form by 31 October. In addition, it was clear in the Declaration that the agreements reached in the negotiations on services trade. It must be based on the promotion of economic growth for all trading partners and the level of economic development of developing 
countries, and to achieve trade liberalization, it urged all Member States to actively participate in the negotiations on services trade[6]. In addition, the requirements of adherence were the following objectives and principles of market opening.

1. The principles of Negotiations in Services Trade.

(1)The principle of differential treatment. Services trade, whether in the whole or individual industries, should take into account the differences between the development of different member states.(2)The interests of middle-income countries. Under certain conditions to retain some of the special rights and interests of developing countries, in particular, they are a certain export advantages and excellent service delivery model of the country.(3)The interests of low-income countries. Understanding the realities of development in low-income countries, it could allow low-income countries which do not make new commitments on issues that related to services trade negotiations[7].

2. The objectives of Negotiations in Services Trade

(1)Reference may be made to the liberalization objectives of the sectorial and model categories proposed by Member States, which is a basis for requesting and responding to negotiations.(2)Members are required to pursue comprehensive and effective implementation of services trade negotiations, and the treatment of special treatment of members of low-income countries should be incorporated into the multilateral trading system in a manner that is beneficial and meaningful to them.(4)Members should intensify their consultations to complete the GATS negotiations on emergency defense measures, government procurement, and subsidy issues within the mandated and revised terms of individual revisions.(5)Members shall, in accordance with the authorization of GATS, regulate relevant national laws and regulations before the end of the Round.

At present, the service sector has become the fastest growing sector in the global economy. According to the basic principles of GATS, the member states should uphold MFN treatment, national treatment, transparency, progressive liberalization, and domestic regulations [8]. As the Doha Round takes place in response to requests and responses, Member States are required to submit a list of market liberalization requirements and responses to further liberalization of the services sector within a specified period of time.

With the current progress, the slow progress of the negotiations, in addition to countries for market openness of some doubts, another important factor is the service trade statistics compilation more difficult [9]. Coupled with some developing countries, the domestic service industry is more the lack of global market competitiveness, if the fear of opening will lead to a significant rebound. However, despite the limitations of their trade statistics, it is the unanimous mission of the member states to press for negotiations on services trade. Therefore, in terms of the latest situation in the negotiations as a whole, WTO member countries, in addition to dozens of multilateral meetings to resolve differences and build consensus, but also advocated from May 15, 2006 until May 23 only, start another A wave of multilateral and bilateral "demand and response" meetings to accelerate the progress of services trade negotiations.

So far, the meeting, started on May 15, 2006, that the services trade negotiations had made great progress in the title, stalled. Among them, the United States for the provision of services trade model, the cross-border movement of natural persons, was no longer plan to do more open concessions [10]. On the other hand, Brazil, based on the ineffectiveness of agricultural negotiations, in the service trade negotiations insisted on that education services was no longer open. The developing countries, led by Brazil and India, had blamed the United States for the disincentives to the negotiations on services trade, and the United States had stressed that too much goodwill had been released in the past and made a lot of promise.

FTA and Negotiations of Services Trade. In view of the good development trend of the service market and the active pursuit of more open markets by all countries. Especially developed countries, many FTA have set services trade as a major development in recent years. According to the 2005 World Bank's report pointed out that the current number of FTA, showing the United States, the European Union and South-South (South-South, among developing countries) as the main trend of the sign. However, since services trade is often the advantage of developed countries, services trade 
will be regarded as the subject of negotiations, but also most of the North-North or North-South bilateral or regional trade agreements. In addition to upholding the GATS requirement, the three main services trade markets are subject to national treatment, most-favored-nation treatment and market access rules. Many countries prefer to adopt the principle of originality in order to promote the Trade. While the United States as the main FTA restrictions on market access is more towards the direction of liberalization, a negative form of presentation.

However, when the global wave of FTA signing contact, we also found that FTA has not reached a more liberalized standards to services trade. For example, telecommunications and financial services sector are significantly slower than the GATS negotiations, the progress of slow, The reason for this is that while developing countries argue that the industries concerned should be more transparent, they are less open than the multilateral framework by the political and economic impact.

In recent years, FTA has been adopted as a more open and flexible approach .It is real meaning continues to be challenged and the need for international trade liberalization which is increasing. For example, on January,1,2004, the formal implementation of the United States and Singapore signed a new free trade agreement. The two countries agreed to open their own service market, and promised to implement national treatment. In particular, Singapore opened its financial markets to the United States and promised that even in the event of an economic crisis; its regulation of funds would be limited. In other words, US investors could freely enter and leave the Singapore market during the financial crisis. The concessions in Singapore, was also the United States signed a new FTA key to the success of the negotiations. The United States and Singapore's FTA in the service trade and the principle of origin, the two sides made significant progress, the two sides agreed to take a negative for services and investments listed way, and developed the most advanced principles of origin, while the two sides in the competition policy and investment policy on the issue, but also to achieve the MFN status of substantive progress. In addition, the United States and Singapore's FTA, Singapore and Australia's FTA further strengthen the norms of transparency and encouraged mutual certification of professional services.

\section{Summary}

The role of services trade in international trade is increasingly important. Countries saw the WTO multilateral negotiations, the complexity and time-consuming, have turned to bilateral, towards multilateral or bilateral parallel way forward. The FTA has not only stimulated the vigorous development of services trade, but also affected regional investment, intellectual property protection, competition policy, domestic regulations and government procurement policies. Despite the fact that the Doha Round could be completed as before, the parties are still inconclusive. However, bilateral or multilateral FTA has set off a wave of trade liberalization. Recently, the FTA signed by all countries has demonstrated high-quality content. The mode of supply of services trade or industry has been more open progress. From this perspective, today's booming free trade agreement, or contribute to the development of multilateral free trade.

Over the past decade, from the distribution of international services trade, developing countries as a new force in the export of international services trade changing the pattern of interests which dominated by developed countries. First, developing countries have broken the long-standing pattern of interests in the international services trade, which accounts for more than $70 \%$ of the developed countries' services trade (accounting for more than $70 \%$ of exports), not only $30 \%$ of the global services trade exports. And in tourism, construction, transportation services, other business services, computer and information services in the five major industrial exports accounted for close to or more than $40 \%$. Second, the world's largest developing countries, China and India have been among the world's top ten list of service trade exporters. Third, transition economies, developing countries, services trade exports more than developed countries, the contribution to the growth of global services trade increased.

As the world's second largest services trade, China should actively and comprehensively participate in the new round of global services trade negotiations rules: First, actively and fully 
participate in the global services trade, To promote global multilateral services trade rules negotiations; Secondly, it is to strive for access to the TISA multilateral trade negotiations; Thirdly, it is to speed up China-Japan-Korea FTA and other regional services trade negotiations. In the new round of negotiations on international services trade, safeguarding the interests of developing countries, the establishment of fair and reasonable new international services trade order.

\section{References}

[1] Yuan Xiao, li Wang Wei. China's Choice in the Negotiation of China-Japan-South Korea Free Trade Area Trade in Services-Based on RCA Index. Contemporary Economy of Japan.2013(04).(In Chinese)

[2] Zhuang Rui; Fang Ling. An Analysis of China-Japan-South Korea Negotiations on Service Trade Based on International Competitiveness Comparison. Journal of International Trade.2013(09).(In Chinese)

[3] Kuang Mei. FTA Pattern in East Asia and China's Strategic Choice. Northeast Asia Forum.2015 (01). (In Chinese)

[4] Guoyou Song, WenJin Yuan. China's Free Trade Agreement Strategies.The Washington Quarterly.2012 (4). (In Chinese)

[5] WTO. Regional Trade Agreements Facts and Figures. http://www.wto.org/english/tratop_e/region_e/region_e.htm

[6] Audrey Guo.CCPIT Builds Innovation Platform to Benefit Enterprise with FTA Policies. China's Foreign Trade.2015(05).(In Chinese)

[7] Ji Wenhua. An Analysis of the Negotiation and Content of WTO Doha Round Dispute Settlement Mechanism. World Trade Organization Focus.2010 (01). (In Chinese)

[8] Liu Xiaobing, the Function of WTO Dispute Settlement Mechanism under the Doha Stalemate. Journal of Yunnan University(Law Edition).2012(05).(In Chinese)

[9] Wang Fangni. On the Reasonable Time Limit for the Implementation of the WTO Dispute Settlement Mechanism. Northern Economy and Trade.2016 (08). (In Chinese)

[10]LI Ying,MEI Xiao. Retrospection and Analysis of China's Application of WTO Dispute Settlement Mechanism. Journal of North China Electric Power University(Social Sciences).2013(01).(In Chinese) 